\title{
Maria, Józef, Marek Półturzyccy, Muzea kobiet polskich, Wydawnictwo Naukowe Instytutu Technologii Eksploatacji- PIB, Warszawa 2017, ss. 249.
}

Muzea polskich kobiet to kolejna publikacja Marii Różańskiej-Półturzyckiej i Józefa Półturzyckiego, którzy podążają śladami wybitnych Polaków. Wcześniejsze dzieła: Muzeum Adama Mickiewicza, Ślady i pamiątki Jana Kochanowskiego oraz Ślady i pamiątki Prymasa Tysiaclecia ukazywały życie wybitnych mężczyzn; tym razem autorzy postanowili przybliżyć sylwetki znanych Polek. Do zespołu autorów dołączył syn - Marek Półturzycki, który jest również autorem większości zdjęć zamieszczonych w książce.

Autorzy znaleźli w Polsce trzydzieści pięć placówek, które poświęcone są twórczości i działalności znanych kobiet, co pozwoliło im na opisanie dwudziestu czterech kobiet. Wśród nich jest dwanaście poetek i pisarek: Maria Dąbrowska, Kazimiera Iłłakowiczówna, Anna Iwaszkiewicz, Maria Konopnicka, Zofia Kossak-Szatkowska, Maria Kownacka, Maria Kuncewiczowa, Zofia Nałkowska, Eliza Orzeszkowa, Halina Poświatowska, Halina Rudnicka i Zofia Urbanowska; pięć świętych i błogosławionych - siostra Elżbieta Czacka, św. Faustyna Kowalska, bł. Karolina Kózka, św. Urszula Ledóchowska, św. Edyta Stein; trzy artystki: Helena Modrzejewska, Mira Zimińska-Sygietyńska i Barbara Ptak; dwie nauczycielki - Wanda Szuman i Olga Drahonowska-Małkowska, oraz jedna nauczycielka-generał - Elżbieta Zawacka, i jedna uczona - Maria Curie-Skłodowska. Cztery z ukazanych muzeów - Olgi z Drahonowskich i Andrzeja Małkowskich, Muzeum im. Anny i Jarosława Iwaszkiewiczów, Dom Marii i Jerzego Kuncewiczów, Muzeum Barbary i Stanisława Ptaków - przedstawiają kobiety w towarzystwie mężczyzn ze względu na wspólną znaczącą działalność. Prezentowane w książce kobiety równocześnie spełniały się w innych sferach życia, np. w działalności oświatowej, społecznej, politycznej. W związku z tym autorzy publikacji zastosowali uporządkowanie alfabetyczne w układzie książki, zaczynając od Marii Curie-Skłodowskiej, a kończąc na Barbarze i Stanisławie Ptakach. 
Ukazane w książce wątki biograficzne nie tylko pokazują, jak wyglądało życie prywatne i zawodowe kobiet, ale również dają czytelnikowi poczucie realności opisanych postaci. Ta realność wiąże się ponadto z drugim poruszanym przez Półturzyckich wątkiem, tj. miejsc upamiętniających te kobiety. Wszelkie muzea i ekspozycje, które są opisane w książce, tworzą przewodnik z jednej strony po Polsce śladami wybitnych kobiet, z drugiej strony po życiu każdej z tych osób z osobna. Jak podkreślają autorzy ważnym elementem, nie tylko dla historii i kultury, ale także dla bliższego poznania danej osoby, jest urządzenie ekspozycji muzealnej począwszy od mebli i koloru ścian, skończywszy na prywatnych biblioteczkach.

Pisarstwo autorów książki odznacza się formułowaniem zwięzłych, przejrzystych myśli. Daje się to dostrzec zwłaszcza w częściach biograficznych, które są rzeczowe i syntetyczne. Autorzy nie wikłają się w zbędne anegdoty; skupiają się raczej na przedstawieniu kolei życia danej bohaterki (bohaterów) w stopniu potrzebnym do nakreślenia kontekstu dla opisu muzeów. Mimo wszystko daje się dostrzec niezwykłe, być może nieuchwytne w słowach, zaangażowanie autorów w poruszaną tematykę.

Niewątpliwym walorem tej publikacji jest fakt, iż przybliżone sylwetki znaczących polskich kobiet ukazują wartość pedagogiczną związaną z biografią danej postaci oraz kultury, w której żyły. Autorzy książki pokazali, że kobiety nie tylko były towarzyszkami wybitnych mężczyzn, ale również ich działalność była znacząca w różnych dziedzinach życia. Można żywić nadzieję, że taki paradygmat będzie sukcesywnie powielany w literaturze. $\mathrm{Z}$ perspektywy własnego pokolenia stwierdzam, że jest to wartościowa i godna polecenia pozycja także dla młodych. 